Exercise training intensity determination in cardiovascular rehabilitation: Should the guidelines be reconsidered?

Peer-reviewed author version

HANSEN, Dominique; Bonné, Kim; Alders, Toon; Hermans, Ann; COPERMANS, Katrien; Swinnen, Hans; Maris, Vincent; Jansegers, Thomas; Mathijs, Wout;

Haenen, Laura; Vaes, Johan; Govaerts, Emmanuela; Reenaers, Veerle; FREDERIX, Ines \& DENDALE, Paul (2019) Exercise training intensity determination in cardiovascular rehabilitation: Should the guidelines be reconsidered?. In: European journal of preventive cardiology (Print), 26(18), p. 1921-1928..

DOI: $10.1177 / 2047487319859450$

Handle: http://hdl.handle.net/1942/29559 


\section{Exercise training intensity determination in cardiovascular rehabilitation: should the guidelines be reconsidered?}

Dominique Hansen, PhD, FESC ${ }^{1-3}$; Kim Bonné, $\mathrm{MSc}^{2}$; Toon Alders, $\mathrm{MSc}^{2}$; Ann Hermans, $\mathrm{BSc}^{2}$; Katrien Copermans, MSc ${ }^{2}$; Hans Swinnen, MSc${ }^{2}$; Vincent Maris, $\mathrm{MSc}^{1}$; Thomas Jansegers, $\mathrm{BSc}^{1}$; Wout Mathijs,

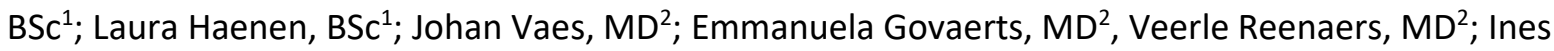
Frederix, MD, $\mathrm{PhD}^{2-4}$; Paul Dendale, MD, PhD, $\mathrm{FESC}^{2,3}$

1. REVAL - Rehabilitation Research Center, Faculty of Rehabilitation Sciences, Hasselt University, Diepenbeek, Belgium

2. Jessa Hospital, Heart Center Hasselt, Hasselt, Belgium

3. BIOMED - Biomedical Research Center, Faculty of Medicine and Life Sciences, Hasselt University, Diepenbeek, Belgium

4. Faculty of Medicine and Health Sciences, Antwerp University, Antwerp, Belgium

\section{Funding}

This study was supported by an unrestricted grant from Hartcentrum Hasselt, vzw.

Full text word count: $\underline{3042}$

Contact details:

REVAL - Rehabilitation Research Center

Faculty of Rehabilitation Sciences

Hasselt University

Agoralaan, Building A,

3590 Diepenbeek

Belgium

e-mail: Dominique.hansen@uhasselt.be

Phone: 0032497875866 


\begin{abstract}
Aims

In the rehabilitation of cardiovascular disease (CVD) patients a correct determination of the endurance-type exercise intensity is important to generate health benefits and preserve medical safety. It remains to be assessed whether the guideline-based exercise intensity domains are internally consistent and agree with physiological responses to exercise in CVD patients.
\end{abstract}

\title{
Methods
}

Two-hundred and seventy-two CVD patients without pacemaker executed a maximal cardiopulmonary exercise test on bike (peak respiratory gas exchange ratio $>1.09$ ), to assess peak $H R\left(H R_{\text {peak }}\right.$ ), oxygen uptake $\left(\mathrm{VO}_{2 \text { peak }}\right)$ and cycling power output $\left(\mathrm{W}_{\text {peak }}\right)$. The first and second ventilatory threshold (VT1 and VT2, respectively) was determined and extrapolated to $\% \mathrm{VO}_{2 \text { peak }} \% \mathrm{HR}_{\text {peak }}$ \%heart rate reserve (\%HRR) and $\% \mathrm{~W}_{\text {peak }}$ for comparison with guideline-based exercise intensity domains.

\section{Results}

VT1 was noticed at $62 \pm 10 \% \mathrm{VO}_{2 \text { peak }}, 75 \pm 10 \% \mathrm{HR}_{\text {peak }}, 42 \pm 14 \% \mathrm{HRR}$ and $47 \pm 11 \% \mathrm{~W}_{\text {peak }}$, corresponding to the high-intense exercise domain (for \%VO2 $2_{\text {peak }}$ and \% $\mathrm{HR}_{\text {peak }}$ ) or low-intense exercise domain (for $\% \mathrm{~W}_{\text {peak }}$ and $\left.\% \mathrm{HRR}\right)$. VT2 was noticed at $84 \pm 9 \% \mathrm{VO}_{2 \text { peak }}, 88 \pm 8 \% \mathrm{HR}_{\text {peak }}, 74 \pm 15 \% \mathrm{HRR}$ and $76 \pm 11 \% \mathrm{~W}_{\text {peak, }}$ corresponding to the high-intense exercise domain (for \%HRR and \% $\mathrm{W}_{\text {peak }}$ ) or very-hard exercise domain (for $\% \mathrm{HR}_{\text {peak }}$ and $\% \mathrm{VO}_{2 \text { peak }}$ ). At best (when using $\% \mathrm{~W}_{\text {peak }}$ ) in only $63 \%$ and $\underline{72} \%$ of all patients VT1 and VT2, respectively, corresponded to the same guideline-based exercise intensity domain, but this dropped to about $48 \%$ and $\underline{52} \%$ at worst (when using $\% \mathrm{HRR}$ and $\% \mathrm{HR}_{\text {peak, }}$ respectively). Particularly the patient's $\mathrm{VO}_{2 \text { peak }}$ related to differently elicited guideline-based exercise intensity domains $(p<0.05)$.

\section{Conclusion}

The guideline-based exercise intensity domains for CVD patients seem inconsistent, thus reiterating the need for adjustment.

Keywords: cardiovascular rehabilitation, exercise intensity, guidelines 


\section{Introduction}

Cardiovascular rehabilitation is important in the treatment and secondary prevention of cardiovascular disease. $^{1-3}$ In patients with coronary artery disease significant reductions in fatal events and hospitalizations, while in patients with heart failure significant reductions in hospitalizations due to cardiac reasons and a trend towards reductions in mortality, were observed. ${ }^{4,5}$

As a result of these positive outcomes, European and American guidelines for the rehabilitation of patients with cardiovascular disease (CVD) have been published, ${ }^{1-3,6-8}$ and CVD rehabilitation decisionsupport systems have been developed, ${ }^{9,10}$ in which the different exercise intensity domains are mentioned, going from low-intense up to maximal effort (see Table 1) ${ }^{6,11,12}$ Such information assists clinicians to select the proper exercise intensity, but also allow them to choose between a variety of different objective parameters to verify this exercise intensity during an exercise session (e.g. heart rate, cycling power output). A proper selection of this exercise intensity is important, since this may be instrumental to the initation of physiological adaptations as well as to preserve the medical safety of exercise intervention. ${ }^{13}$ For example, to reduce blood pressure, increase endurance exercise capacity in a time-efficient manner, and elicit a significant energy expenditure during endurance exercise (to reduce adipose tissue mass) at least moderate-intense exercise is advised..$^{14,15}$ Moreover, to prevent adverse cardiovascular events during endurance exercise in previously sedentary individuals, sustained high-intense exercise should not be preferred in the first weeks of intervention. ${ }^{16,17}$ However, it remains to be verified in greater detail whether the different guideline-based exercise intensity domains are internally consistent and agree with the physiological responses to exercise in patients with CVD. In order to quantify to what extent a patient with CVD exercises in the aerobic or anaerobic exercise intensity domain the first and second ventilatory threshold (VT1 and VT2, respectively) can be determined. ${ }^{9}$ These thresholds are much better tailored to the patient's exercise performance and phenotype, in contrast to methods in which a percentage of peak performance is taken. Indeed, CVD patients may show significantly different transition speeds to anaerobic metabolism during incremental exercise (in part due to ventilatory, cardiovascular or muscular abnormalities, surgery, medication intake and/or physical activity level), and thus different VT1's and VT2's may emerge, even when a similar peak oxygen uptake $\left(\mathrm{VO}_{2 \text { peak }}\right)$ or peak heart rate $\left(\mathrm{HR}_{\text {peak }}\right)$ is achieved. ${ }^{11,12}$ As a result, in CVD patients it remains to be verified whether the guideline-based exercise intensity domains (which mainly focus on percentages of peak performance) are internally consistent and agree with the individual physiological response to exercise (which relate to VT1 and VT2).

The aim of this study was to compare the elicited exercise responses at VT1 and VT2 (expressed as $\% \mathrm{VO}_{2 \text { peak }} \% \mathrm{HR}_{\text {peak }} \% \mathrm{~W}_{\text {peak }}$ and $\% \mathrm{HRR}$ ) with the guideline-based exercise intensity domains for $\mathrm{CV}$ rehabilitation. It was hypothesized that VT1 and VT2 would correspond to proper guideline-based 
exercise intensity domains, with high internal consistency of these intensity domains within the guidelines.

\section{Methods}

Population and design

This was a prospective cross-sectional study. From April 2015 up to February 2017, patients with cardiovascular disease (mainly coronary artery disease or heart failure) who started an outpatient rehabilitation program at Jessa hospital, Hasselt, Belgium, were invited to sign an informed consent (approved by the medical ethical committee of Jessa hospital, registration nr: B243201629466) explaining in detail the nature and risks of this study, and to execute a maximal cardiopulmonary exercise test (CPET) on bike. From 450 patients who were screened for participation, patients were excluded because they were not willing to sign an informed consent $(n=34)$, had a pacemaker $(n=35)$, suffered from significant pulmonary (e.g. COPD, previous pulmonary surgery), neurologic (e.g. CVA, Parkinson's disease) and/or orthopaedic disease (e.g. knee or hip arthrosis) that would limit exercise performance $(n=53)$. In addition, 48 patients did not deliver maximal effort during CPET (respiratory gas exchange ratio $<1.10$ ) and eight patients were not in sinus rhythm during $C P E T$, and were thus also excluded from analysis. Therefore, 272 patients were maintained for final analysis (see Fig. 1 for study flowchart).

\section{Assessments}

In fed condition body height was measured to the nearest $0.1 \mathrm{~cm}$ using a wall-mounted Harpenden stadiometer (ICD 250 DW, De Grood Metaaltechniek, Nijmegen, The Netherlands), with participants barefoot. Body weight (in underwear) was determined using a digital-balanced weighting scale to the nearest $0.1 \mathrm{~kg}$ (Seca 770, Seca Hamburg, Germany). Body mass index (BMI) was calculated from weight and height measurements (weight/height ${ }^{2}$ ).

Based on the clinical evaluation ahead of CPET, the patient's CVD risk profile (presence of hypertension, dyslipidaemia, diabetes mellitus) was compiled. In addition, medication intake was noted.

The CPET was performed up to volitional exhaustion using an electronically braked cycle ergometer (eBike, GE Medical systems, Milwaukee, Wisconsin, USA), controlled by the Cardiosoft electrocardiography software (Cardiosoft 6.6, GE Medical systems, Freiburg, Germany). At the beginning of each test day, a gas and volume calibration was performed according to manufacturer's instructions. During the test, environmental temperature was kept stable at $19-21^{\circ} \mathrm{C}$. The exercise test (ramp protocol) included a 30 -sec pre-exercise resting period sitting upright on bike, a 1-to-2-min unloaded warm-up cycling phase, followed by an incremental exercise cycling period with an initial 
workload of 10-60 W, and an increasing workload of 5-40W per minute, dependent on the patient's clinical status (with the aim to complete the CPET within 6-12 minutes). During warm-up cycling and incremental exercise, a cycling frequency of 60-70 revolutions per minute (rpm) had to be maintained. The test was ended when the subject failed to maintain a pedal frequency of at least $60 \mathrm{rpm}$. All subjects were verbally encouraged during exercise testing to achieve maximal effort, based on a RER $\geq 1.10$ and subjective opinion of an experienced tester who confirmed whether a maximal exercise test was executed, based on subjective features (e.g. dyspnoea, sweating, facial flushing, clear unwillingness to continue, and/or a sustained drop in the participant's pedalling frequency from 60 rpm despite verbal encouragement). With the aid of continuous pulmonary gas exchange analysis (Jaeger MasterScreen CPX Metabolic Cart, CareFusion Germany GmbH, Hoechberg, Germany) oxygen uptake $\left(\mathrm{VO}_{2}\right)$, carbon dioxide output $\left(\mathrm{VCO}_{2}\right)$, minute ventilation (VE), equivalents for oxygen uptake $\left(\mathrm{VE} / \mathrm{VO}_{2}\right)$ and carbon dioxide production $\left(\mathrm{VE} / \mathrm{VCO}_{2}\right)$ and the RER were collected breath-by-breath and averaged every ten seconds. Using a 12-lead electrocardiography device (KISS ${ }^{\mathrm{TM}}$ Multilead, GE Medical systems, Freiburg, Germany) HR was monitored and averaged every 10 seconds. Exercise tolerance was also assessed by the peak workload ( $\mathrm{W}_{\text {peak }}$ ). The first ventilatory threshold (VT1) was determined using the V-slope method, and this threshold was double-checked by establishing the nadir of the $\mathrm{VE} / \mathrm{VO}_{2}$ versus work rate relationship. ${ }^{11,12}$ The VT1 marks the limit between the light-to-moderate and the moderate-to-high intensity effort domains. ${ }^{11,12}$ Next, the second ventilatory threshold (VT2) was determined, using the VE vs. $\mathrm{VCO}_{2}$ plot, on the point where $\mathrm{VE}$ increases out of proportion to $\mathrm{VCO}_{2}$, and this threshold was double-checked by establishing the nadir of the $\mathrm{VE} / \mathrm{VCO}_{2}$ versus $\mathrm{W}$ relationship. ${ }^{11,12}$ The VT2 is considered to be related to the critical power, which is the upper intensity limit for prolonged aerobic exercise. ${ }^{11,12}$ These ventilatory thresholds were determined by two independent observers who cross-checked each other's work. A third independent observer then reviewed these thresholds in a random subsample of patients. For every patient, consensus on VT1 and VT2 was achieved. VT2 could not be determined in 10 patients. However, since VT1 could be determined in these patients, they were maintained for analysis.

At VT1 and VT2, $\mathrm{VO}_{2}, \mathrm{HR}$ and $\mathrm{W}$ was determined to calculate $\% \mathrm{VO}_{2 \text { peak, }} \% \mathrm{HR}_{\text {peak }}$ and $\% \mathrm{~W}_{\text {peak. }}$. From these data and the resting HR, the achieved HRR was additionally calculated and expressed as \%HRR.

\section{Statistical analysis}

Statistical analysis was performed by IBM SPSS ${ }^{\circledR}$ version 24.0 (IBM SPSS Statistics for Windows, Chicago, IL, USA). According to Shapiro-Wilk test the data were normally distributed ( $p>0.05)$. Data were therefore expressed as means $\pm S D$. After a descriptive data analysis, multivariate regression models were built to analyse independent relations between $\% \mathrm{VO}_{2 \text { peak }}, \% \mathrm{HR}_{\text {peak }} \% \mathrm{HRR}, \% \mathrm{~W}_{\text {peak }}$ at VT1 and VT2, and the subject's age, sex, BMI, physical fitness $\left(\mathrm{VO}_{\text {2peak }}\right.$ in $\left.\mathrm{ml} / \mathrm{kg} / \mathrm{min}\right)$, medication intake, 
type of cardiac disease and/or surgical intervention. In addition, univariate correlations were examined by Pearson coefficients. In final, the total group was divided in patients achieving a $\mathrm{VO}_{2 \text { peak }}<15.0$ $\mathrm{ml} / \mathrm{kg} / \mathrm{min}$ (worst performance group) vs. $\geq 25 \mathrm{ml} / \mathrm{kg} / \mathrm{min}$ (best performance group) and compared by one-way ANOVA for $\% \mathrm{VO}_{2 \text { peak, }} \% \mathrm{HR}_{\text {peak }}, \% \mathrm{HRR}, \% \mathrm{~W}_{\text {peak }}$ at VT1 and VT2. A p-value $<0.05$ (two-tailed) was considered statistically significant.

\section{Results}

\section{Subject characteristics}

In this study, mainly male patients (72\% of total group) with coronary artery disease ( $80 \%$ of total group) were examined. The majority of patients were revascularised by PCI (59\% of total group), were overweight (BMI $\left.27.0 \pm 4.7 \mathrm{~kg} / \mathrm{m}^{2}\right)$ and suffered from exercise intolerance $\left(V_{2 \text { peak }} 19.3 \pm 5.4 \mathrm{ml} / \mathrm{kg} / \mathrm{min}\right)$ (see Table 2). In $22 \%$ of patients with heart failure it was known to be of known ischemic origin. In addition, most patients were on beta-blocker ( $78 \%$ of total group), antiplatelet ( $88 \%$ of total group) and statin ( $82 \%$ of total group) therapy. From $\operatorname{RER}_{\text {peak }}(1.26 \pm 0.10)$ all exercise tests were verified as maximal.

The first and second ventilatory threshold in relation to guideline-based exercise intensity domains The first ventilatory threshold was noticed at $62 \pm 10 \%$ of $\mathrm{VO}_{2 \text { peak, }} 75 \pm 10 \%$ of $\mathrm{HR}_{\text {peak }}, 42 \pm 14 \%$ of $\mathrm{HRR}$ and $47 \pm 11 \%$ of $W_{\text {peak. }}$ For the majority of the patients these responses corresponded to the high-intense exercise domain (for \%VO2 2 peak and \% $\mathrm{HR}_{\text {peak }}$ ), and low-intense exercise domain (for \%HRR and \% $\mathrm{W}_{\text {peak }}$ ) (Table 3, grey areas). As a result, at a same level of effort (which could be considered as low-intense), very different guideline-based exercise intensity domains were elicited.

The second ventilatory threshold was noticed at $84 \pm 9 \%$ of $\mathrm{VO}_{2 \text { peak }}, 88 \pm 8 \%$ of $\mathrm{HR}_{\text {peak }}, 74 \pm 15 \%$ of $\mathrm{HRR}$ and $76 \pm 11 \%$ of $W_{\text {peak. }}$ For the majority of the patients these responses corresponded to the highintense exercise domain (for \%HRR and \% $\mathrm{W}_{\text {peak }}$ ), and to the very-hard exercise domain (for \%HR peak and $\% \mathrm{VO}_{2 \text { peak }}$ ) in the guidelines (Table 3 , grey areas). Here, at a same level of effort (which could be considered as moderate-to-high intense), different guideline-based exercise intensity domains were elicited.

\section{Multi-and univariate correlation analysis}

It was further examined what patient characteristics could predict the difference in elicited exercise intensity domains. According to multivariate regression analyses, the only parameter that consistently and independently related to $\% \mathrm{VO}_{2 \text { peak }} \% \mathrm{HR}_{\text {peak }} \% \mathrm{HRR}, \% \mathrm{~W}_{\text {peak }}$ at VT1 and VT2 across all eight regression models (model $\mathrm{p}<0.05)$, was the patient's $\mathrm{VO}_{2 \text { peak }}(\mathrm{ml} / \mathrm{kg} / \mathrm{min}$ ). Medication intake, type of cardiovascular disease or surgery, age and sex was not independently related to $\% \mathrm{VO}_{2 \text { peak, }} \% \mathrm{HR}_{\text {peak }}$, 
\%HRR, \% $\mathrm{W}_{\text {peak }}$ at VT1 and VT2. As a result, univariate correlations between the patient's $\mathrm{VO}_{2 \text { peak }}$ $(\mathrm{ml} / \mathrm{kg} / \mathrm{min})$ and $\% \mathrm{VO}_{2 \text { peak }}, \% \mathrm{HR}_{\text {peak, }} \% \mathrm{HRR}, \% \mathrm{~W}_{\text {peak }}$ at VT1 and VT2 are shown in Table 4: a higher $\mathrm{VO}_{2 \text { peak }}$ was associated with lower elicited exercise intensities at VT1 and VT2.

Comparison between physically fit vs. deconditioned patients

Patients with the worst exercise tolerance $\left(\mathrm{VO}_{2 \text { peak }}<15.0 \mathrm{ml} / \mathrm{kg} / \mathrm{min}(\mathrm{n}=\underline{55})\right)$ achieved a significantly greater $\% \mathrm{VO}_{2 \text { peak, }} \% \mathrm{HRR}, \% \mathrm{~W}_{\text {peak }}$ at $\mathrm{VT} 1$ and $\mathrm{VT} 2$, as opposed to patients with the best exercise tolerance $\left(\mathrm{VO}_{2 \text { peak }} \geq 25.0 \mathrm{ml} / \mathrm{kg} / \mathrm{min}(\mathrm{n}=40)\right)(p<0.05$, see Table 5$)$. Moreover, in physically fitter patients a greater consistency of the exercise intensity domains within the guidelines were noticed at VT2, when compared to less physically fit patients (grey areas in Table 5). 


\section{Discussion}

In the present study, it was observed that at a same level of effort (whether this was at VT1 or at VT2), different guideline-based exercise intensity domains within the guidelines were elicited. Moreover, in patients with a lower $\mathrm{VO}_{2 \text { peak }}$ systematically higher exercise intensities domains were elicited at VT1 and VT2, as opposed to patients with a higher $\mathrm{VO}_{2 \text { peak. }}$

In the present cohort VT1 was noticed at $62 \pm 10 \%$ of $\mathrm{VO}_{2 \text { peak }}, 75 \pm 10 \%$ of $H R_{\text {peak }}, 42 \pm 14 \%$ of $\mathrm{HRR}$ and $47 \pm 11 \%$ of $W_{\text {peak. }}$. For the majority of the patients these responses corresponded to the guideline-based high-intense exercise domain (for $\% \mathrm{VO}_{2 \text { peak }}$ and $\% \mathrm{HR}_{\text {peak }}$ ), and low-intense exercise domain (for $\% \mathrm{~W}_{\text {peak }}$ and \%HRR). At a relatively same level of effort (VT1, which could be considered as low-intense), very different guideline-based exercise intensity domains were elicited. In the best case scenario (when using $\% \mathrm{~W}_{\text {peak }}$ ) in only about $63 \%$ of all patients VT1 corresponds to the same guideline-based exercise intensity domain, and this dropped to about $48 \%$ in the worst case scenario (when using \%HRR). This finding may thus point towards inconsistencies between the guideline-based exercise intensity domains, and thus should deserve adjustment.

The same observations were made for VT2. The second ventilatory threshold was noticed at $84 \pm 9 \%$ of $\mathrm{VO}_{2 \text { peak, }} 88 \pm 8 \%$ of $\mathrm{HR}_{\text {peak }}, 74 \pm 15 \%$ of $\mathrm{HRR}$ and $76 \pm 11 \%$ of $\mathrm{W}_{\text {peak. }}$. For the majority of the patients these responses corresponded to the very-hard exercise domain (for $\% \mathrm{HR}_{\text {peak }}$ and $\% \mathrm{VO}_{2 \text { peak }}$ ), and high-intense exercise domain (for \%HRR and \% $\mathrm{W}_{\text {peak }}$ ). Also here, at a same level of effort (which could be considered as moderate-to-high intense), different guideline-based exercise intensity domains were elicited. In the best case scenario (when using $\% \mathrm{~W}_{\text {peak }}$ ) in only about $\underline{72} \%$ of all patients VT2 corresponds to the same guideline-based exercise intensity domain, and this dropped to about $52 \%$ in the worst case scenario (when using \%HR $\mathrm{Reak}_{\text {) }}$.

Whether different exercise intensity parameters correspond with each other has been studied before, but with mixed outcomes and often in smaller studies (maximal $n=115) \cdot{ }^{18-21}$ A more recent study involving 141 patients with heart disease found that the use of HR to determine a proper exercise intensity should be done cautiously due to a high inter-patient variance. ${ }^{22}$ It thus follows that these more recent data are well in line with our findings. The current study contributes to a greater insight in how to determine the exercise intensity in CVD patients as a large sample was studied ( $\mathrm{n}=\underline{\mathbf{2 7 2}})$, in which direct comparisons were made with European and American cardiac rehabilitation guidelines. How to determine and set the exercise intensity in the rehabilitation of CVD patients may however be important. A recent randomized controlled trial observed that when healthy individuals exercised according to a specific HRR for twelve weeks, five out of 12 of individuals ( $42 \%$ of total group) experienced a favourable change in relative $\mathrm{VO}_{2 \text { peak }}(\Delta>5.9 \%)$, while when individuals exercised according to the VT1-VT2 training zone relative $\mathrm{VO}_{2 \text { peak }}$ improved $(\Delta>5.9 \%)$ in all $(12 / 12)$ subjects 
( $p<0.05$ for interaction effects). ${ }^{23}$ This finding was recently reproduced in 39 sedentary healthy adults in another randomized trial, ${ }^{24}$ but this remains to be confirmed in CVD patients.

Why there seems to be a significant discrepancy between the individual physiological response to exercise and the different guideline-based exercise intensity domains, is an important issue to resolve. From our data, it was noticed that CVD patients with the best $\mathrm{VO}_{2 \text { peak }}(\geq 25.0 \mathrm{ml} / \mathrm{kg} / \mathrm{min})$ showed systematically lower elicited guideline-based exercise intensity domains, and with greater consistency between the different exercise intensity domains within the guidelines at VT2, when compared to patients with the worst exercise capacity $\left(\mathrm{VO}_{2 \text { peak }}<15.0 \mathrm{ml} / \mathrm{kg} / \mathrm{min}\right)$. Or, to put it into in other words, the current exercise intensity determination guidelines can be used with greater accuracy in physically fit CVD patients, but to a lesser extent in deconditioned patients. None of the other examined patient characteristics could explain the heterogeneity in exercise intensity determination. It is important to stress that the current guidelines actually (re-)use exercise intensity domains as examined and validated in healthy individuals, ${ }^{25}$ which are obviously physically fitter than CVD patients, and not taking medications or suffering from significant diseases which may compromise ventilatory, cardiovascular and/or muscular function. This may thus, at least in part, explain discrepancies between the individual physiological responses to exercise and the different guideline-based exercise intensity domains. In addition, this finding also stresses the need for specific exercise intensity domains for patients with CVD, which can be achieved by the execution of large cohort studies.

This study may be limited by the (well-known) inter-observer variability in the determination of VT. On the other hand, in order this minimize this potential bias the VT's were determined by two independent observers who cross-checked each other's work, and a third independent observer then reviewed these thresholds in a random subsample of patients. Moreover, for every patient, consensus on VT1 and VT2 was achieved. In addition, when compared to another recent study with a large cohort ( $n=141$ CVD patients), ${ }^{22}$ VT1 and VT2 were determined at exactly the same $\% \mathrm{VO}_{2 \text { peak }}\left(\sim 63 \% \mathrm{VO}_{2 \text { peak }}\right.$ and $\sim 83 \% \mathrm{VO}_{2 \text { peak, }}$, respectively) and \%HR peak $\left(\sim 75 \% \mathrm{HR}_{\text {peak }}\right.$ and $\sim 88 \% \mathrm{HR}_{\text {peak }}$, respectively) as in the present study for the total group. In fact, regardless as to whether VT1 and VT2 could be determined in a valid and reliable manner, discrepancies within the different guideline-based exercise intensity domains were still noticed. Moreover, a more mixed population was studied in which the origin for heart failure was not always known. The majority of patients were males and under beta-blocker treatment, and analysis of subpopulations was not possible due to the sample size: the results of this study thus cannot be generalized to all CVD patients and require verification in larger cohorts of patients with different CVD's. 


\section{Conclusions}

In patients with CVD, and especially in deconditioned patients, at a same level of effort, different exercise intensity domains within the guidelines were elicited. These data may reiterate the need to reconsider the different exercise intensity domains in the guidelines.

\section{Acknowledgements}

Conflicts of interest: none to be declared. 


\section{Authorship}

$\mathrm{DH}$ and PD contributed to the conception or design of the work. DH, TA, AH, KC, HS, VM, TJ, WM, LH, JV, EG, VR, and IF contributed to the acquisition, analysis, or interpretation of data for the work. DH drafted the manuscript. $D H, K B, T A, A H, K C, H S, V M, J V, E G, V R$, IF, and PD critically revised the manuscript. All gave final approval and agree to be accountable for all aspects of work ensuring integrity and accuracy. 


\section{References}

1. Piepoli MF, Hoes AW, Agewall S, et al. 2016 European Guidelines on cardiovascular disease prevention in clinical practice. Eur J Prev Cardiol 2016; 23: NP1-NP96.

2. Piepoli MF, Corrà U, Benzer W, et al. Secondary prevention through cardiac rehabilitation: from knowledge to implementation. A position paper from the Cardiac Rehabilitation Section of the European Association of Cardiovascular Prevention and Rehabilitation. Eur J Cardiovasc Prev Rehabil 2010; 17: 1-17.

3. Bjarnason-Wehrens B, Mayer-Berger W, Meister ER, et al. Recommendations for resistance exercise in cardiac rehabilitation. Recommendations of the German Federation for Cardiovascular Prevention and Rehabilitation. Eur J Cardiovasc Prev Rehabil 2004; 11: 352-361.

4. Rauch B, Davos CH, Doherty P, et al. The prognostic effect of cardiac rehabilitation in the era of acute revascularisation and statin therapy: A systematic review and meta-analysis of randomized and non-randomized studies - The Cardiac Rehabilitation Outcome Study (CROS). Eur J Prev Cardiol 2016; 23: 1914-1939.

5. Lewinter C, Doherty P, Gale CP, et al. Exercise-based cardiac rehabilitation in patients with heart failure: a meta-analysis of randomised controlled trials between 1999 and 2013. Eur J Prev Cardiol 2015; 22: 1504-1512.

6. Vanhees L, Geladas N, Hansen D, et al. Importance of characteristics and modalities of physical activity and exercise in the management of cardiovascular health in individuals with cardiovascular risk factors: recommendations from the EACPR. Part II. Eur J Prev Cardiol 2012; 19: $1005-1033$.

7. Vanhees L, Rauch B, Piepoli M, et al. Importance of characteristics and modalities of physical activity and exercise in the management of cardiovascular health in individuals with cardiovascular disease (Part III). Eur J Prev Cardiol 2012; 19: 1333-1356.

8. Fletcher GF, Ades PA, Kligfield P, et al. Exercise standards for testing and training: a scientific statement from the American Heart Association. Circulation 2013; 128: 873-934.

9. Hansen D, Coninx K, Dendale P. The EAPC EXPERT tool. Eur Heart J 2017; 38: 2318-2320.

10. Hansen D, Dendale P, Coninx K, et al. The European Association of Preventive Cardiology Exercise Prescription in Everyday Practice and Rehabilitative Training (EXPERT) tool: A digital training and decision support system for optimized exercise prescription in cardiovascular disease. Concept, definitions and construction methodology. Eur J Prev Cardiol 2017; 24: 10171031.

11. Mezzani A, Hamm LF, Jones AM, et al. Aerobic exercise intensity assessment and prescription in cardiac rehabilitation: a joint position statement of the European Association for Cardiovascular Prevention and Rehabilitation, the American Association of Cardiovascular and 
Pulmonary Rehabilitation and the Canadian Association of Cardiac Rehabilitation. Eur J Prev Cardiol 2013; 20: 442-467.

12. Mezzani A, Hamm LF, Jones AM, et al. Aerobic exercise intensity assessment and prescription in cardiac rehabilitation: a joint position statement of the European Association for Cardiovascular Prevention and Rehabilitation, the American Association of Cardiovascular and Pulmonary Rehabilitation, and the Canadian Association of Cardiac Rehabilitation. J Cardiopulm Rehabil Prev 2012; 32: 327-350.

13. Hansen D, Stevens A, Eijnde BO, et al. Endurance exercise intensity determination in the rehabilitation of coronary artery disease patients: a critical re-appraisal of current evidence. Sports Med 2012; 42: 11-30.

14. Hansen D, Niebauer J, Cornelissen V, et al. Exercise Prescription in Patients with Different Combinations of Cardiovascular Disease Risk Factors: A Consensus Statement from the EXPERT Working Group. Sports Med 2018; 48: 1781-1797.

15. Gomes-Neto $M$, Durães AR, et al. High-intensity interval training versus moderate-intensity continuous training on exercise capacity and quality of life in patients with coronary artery disease: A systematic review and meta-analysis. Eur J Prev Cardiol 2017; 24: 1696-1707.

16. Bartsch P. Platelet activation with exercise and risk of cardiac events. Lancet 1999; 354: 17471837.

17. Cadroy Y, Pillard F, Sakariassen KS, et al. Strenuous but not moderate exercise increases the thrombotic tendency in healthy sedentary male volunteers. J Appl Physiol 2002; 93: 829-833

18. Nieuwland W, Berkhuysen MA, Van Veldhuisen DJ, et al. Individual assessment of intensitylevel for exercise training in patients with coronary artery disease is necessary. Int J Cardiol 2002; 84: 15-20.

19. Omiya $\mathrm{K}$, Itoh $\mathrm{H}$, Osada $\mathrm{N}$, et al. Impaired heart rate response during incremental exercise in patients with acute myocardial infarction and after coronary artery bypass grafting: evaluation of coefficients with Karvonen's formula. Jpn Circ J 2000; 64: 851-855.

20. Chaloupka V, ElbI L, Nehyba S, et al. Exercise intensity prescription after myocardial infarction in patients treated with beta-blockers. J Cardiopulm Rehabil 2005; 25: 361-365.

21. Tabet JY, Meurin $P$, Ben Driss $A$, et al. Determination of exercise training heart rate in patients on beta-blockers after myocardial infarction. Eur J Cardiovasc Prev Rehabil 2006; 13: 538-543.

22. Díaz-Buschmann I, Jaureguizar KV, Calero MJ, et al. Programming exercise intensity in patients on beta-blocker treatment: the importance of choosing an appropriate method. Eur J Prev Cardiol 2014; 21: 1474-1480. 
23. Wolpern AE, Burgos DJ, Janot JM, et al. Is a threshold-based model a superior method to the relative percent concept for establishing individual exercise intensity? A randomized controlled trial. BMC Sports Sci Med Rehabil 2015; 7: 16.

24. Weatherwax RM, Harris NK, Kilding AE, et al. Incidence of VO2max Responders to Personalized vs Standardized Exercise Prescription. Med Sci Sports Exerc 2019; 51: 681-691.

25. Garber CE, Blissmer B, Deschenes MR, et al; American College of Sports Medicine. American College of Sports Medicine position stand. Quantity and quality of exercise for developing and maintaining cardiorespiratory, musculoskeletal, and neuromotor fitness in apparently healthy adults: guidance for prescribing exercise. Med Sci Sports Exerc 2011; 43: 1334-1359. 


\section{Tables}

Table 1 Different exercise intensity domains according to the $\mathrm{CV}$ rehabilitation guidelines ${ }^{6,9,10}$

\begin{tabular}{|c|c|c|c|c|}
\hline & \multicolumn{4}{|c|}{ Parameter } \\
\hline & $\% \mathrm{VO}_{2 \text { peak }}$ & $\% \mathrm{HRR}$ & $\% \mathrm{HR}_{\text {peak }}$ & W $_{\text {peak }}$ \\
\hline Intensity domain & & & & \\
\hline Low-intense & $25-44$ & $20-39$ & $35-54$ & Around 50 \\
\hline Moderate-intense & $45-59$ & $40-59$ & $55-69$ & $50-70$ \\
\hline High-intense & $60-84$ & $60-84$ & $70-89$ & $70-99$ \\
\hline Very hard & $>84$ & $>84$ & $>89$ & 100 \\
\hline Maximal & 100 & 100 & 100 & 100 \\
\hline
\end{tabular}

Abbreviations: $\mathrm{VO}_{2 \text { peak }}$, peak oxygen uptake; $\mathrm{HR}_{\text {peak }}$, peak heart rate; $\mathrm{HRR}$, heart rate reserve; $\mathrm{W}_{\text {peak, }}$ peak cycling power output 
Table 2 Subject characteristics $(n=272)$

\begin{tabular}{|c|c|}
\hline General characteristics & means $\pm S D$ or perce \\
\hline age (years) & $63 \pm 11$ \\
\hline sex (\%males) & 72 \\
\hline body weight (kg) & $80 \pm 17$ \\
\hline body mass index $\left(\mathrm{kg} / \mathrm{m}^{2}\right)$ & $27.0 \pm 4.7$ \\
\hline \multicolumn{2}{|l|}{ Cardiovascular disease } \\
\hline suffered from acute myocardial infarction (\%) & 33 \\
\hline revascularised by CABG (\%) & 10 \\
\hline revascularised by $\mathrm{PCl}(\%)$ & 59 \\
\hline revascularised by endo-ACAB (\%) & 11 \\
\hline \multicolumn{2}{|l|}{ revascularised arteries } \\
\hline circumflex artery (\%) & 20 \\
\hline right ascending artery (\%) & 29 \\
\hline left anterior descending artery (\%) & 49 \\
\hline heart failure (\%) & 13 \\
\hline left ventricular ejection fraction (\%) & $35 \pm 12$ \\
\hline valve disease (\%) & 6 \\
\hline Implantable cardioverter defibrillator (\%) & 3 \\
\hline \multicolumn{2}{|l|}{ Cardiovascular risk factors } \\
\hline hypertension (\%) & 52 \\
\hline dyslipidaemia (\%) & 68 \\
\hline diabetes mellitus (\%) & 12 \\
\hline \multicolumn{2}{|l|}{ Medication } \\
\hline beta blockers (\%) & 78 \\
\hline calcium antagonists (\%) & 11 \\
\hline angiotensin converting enzyme inhibitors (\%) & 43 \\
\hline diuretics (\%) & 16 \\
\hline antiplatelets (\%) & 88 \\
\hline statins (\%) & 82 \\
\hline nitrates (\%) & 12 \\
\hline amiodarone (\%) & 8 \\
\hline \multicolumn{2}{|l|}{ Exercise tolerance } \\
\hline peak oxygen uptake (ml/min) & $1530 \pm 481$ \\
\hline peak oxygen uptake (ml/kg/min) & $19.3 \pm 5.4$ \\
\hline peak cycling power output (W) & $127 \pm 46$ \\
\hline peak heart rate (bts/min) & $120 \pm 22$ \\
\hline RERpeak & $1.26 \pm 0.10$ \\
\hline first ventilatory threshold $\left(\mathrm{ml} / \mathrm{min} \mathrm{VO}_{2}\right)$ & $924 \pm 276$ \\
\hline second ventilatory threshold $\left(\mathrm{ml} / \mathrm{min} \mathrm{VO}_{2}\right)$ & $1276 \pm 381$ \\
\hline
\end{tabular}

Abbreviations: $C A B G$, coronary artery bypass graft surgery; $\mathrm{PCl}$, percutaneous coronary intervention; endo-ACAB, atraumatic CABG; RER, respiratory gas exchange ratio; $\mathrm{VO}_{2}$, oxygen uptake 
Table 3 Distribution of individual responses (VT1 and VT2, n=272) and their frequency of occurrence in correspondence to the guidelines (in grey)

\begin{tabular}{|c|c|c|c|c|c|c|c|c|}
\hline & \multicolumn{4}{|c|}{ First ventilatory threshold } & \multicolumn{4}{|c|}{ Second ventilatory threshold } \\
\hline Observations & $\% \mathrm{VO}_{2 \text { peak }}$ & $\% H R_{\text {peak }}$ & $\% H R R$ & $\% W_{\text {peak }}$ & $\% \mathrm{VO}_{2 \text { peak }}$ & $\% \mathrm{HR}_{\text {peak }}$ & \%HRR & $\% \mathrm{~W}_{\text {peak }}$ \\
\hline Average $\pm S D$ & $62 \pm 10$ & $75 \pm 10$ & $42 \pm 14$ & $47 \pm 11$ & $84 \pm 9$ & $88 \pm 8$ & $74 \pm 15$ & $76 \pm 11$ \\
\hline $\begin{array}{l}\text { Guidelines (\% prevalence of } \\
\text { total group }\end{array}$ & $\% \mathrm{VO}_{2 \text { peak }}$ & $\% \mathrm{HR}_{\text {peak }}$ & \%HRR & $\% W_{\text {peak }}$ & $\% \mathrm{VO}_{2 \text { peak }}$ & $\% H R_{\text {peak }}$ & \%HRR & $\% \mathrm{~W}_{\text {peak }}$ \\
\hline Low-intense & 3.7 & 1.8 & 47.8 & 63.2 & 0 & 0 & 0.8 & 0 \\
\hline Moderate-intense & 34.9 & 27.9 & 43.3 & 33.5 & 1.1 & 1.1 & 16.0 & 27.9 \\
\hline High-intense & 59.6 & 63.2 & 7.8 & 3.3 & 45.4 & 46.6 & 55.7 & 72.1 \\
\hline Very hard & 1.8 & 7.0 & 1.1 & 0 & 53.4 & 52.3 & 27.5 & 0 \\
\hline
\end{tabular}

Abbreviations: $\mathrm{VO}_{2 \text { peak }}$, peak oxygen uptake; $\mathrm{HR}_{\text {peak }}$, peak heart rate; $\mathrm{HRR}$, heart rate reserve; $\mathrm{W}_{\text {peak, }}$ peak cycling power output 


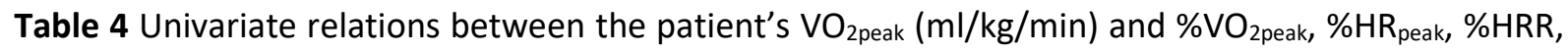
$\% \mathrm{~W}_{\text {peak }}$ at VT1 and VT2 (n=272)

\begin{tabular}{|c|c|c|}
\hline & & $\mathrm{VO}_{2 \text { peak }}(\mathrm{ml} / \mathrm{kg} / \mathrm{min})$ \\
\hline \multirow[t]{2}{*}{$\% \mathrm{VO}_{2 \text { peak }}$ at $\mathrm{VT1}$} & Pearson Correlation & $-0,420$ \\
\hline & Sig. (2-tailed) & $<, 0001$ \\
\hline \multirow[t]{2}{*}{$\% \mathrm{HR}_{\text {peak }}$ at VT1 } & Pearson Correlation & $-0,431$ \\
\hline & Sig. (2-tailed) & $<, 0001$ \\
\hline \multirow[t]{2}{*}{ \%HRR at VT1 } & Pearson Correlation & $-0,153$ \\
\hline & Sig. (2-tailed) & ,012 \\
\hline \multirow[t]{2}{*}{$\% \mathrm{~W}_{\text {peak }}$ at VT1 } & Pearson Correlation & $-0,211$ \\
\hline & Sig. (2-tailed) & $<, 001$ \\
\hline \multirow{2}{*}{$\% \mathrm{VO}_{2 \text { peak }}$ at VT2 } & Pearson Correlation & $-0,368$ \\
\hline & Sig. (2-tailed) & $<, 0001$ \\
\hline \multirow[t]{2}{*}{$\% \mathrm{HR}_{\text {peak }}$ at VT2 } & Pearson Correlation & $-0,290$ \\
\hline & Sig. (2-tailed) & $<, 0001$ \\
\hline \multirow[t]{2}{*}{$\% H R R$ at VT2 } & Pearson Correlation & $-0,128$ \\
\hline & Sig. (2-tailed) & ,039 \\
\hline \multirow[t]{2}{*}{$\% \mathrm{~W}_{\text {peak }}$ at VT2 } & Pearson Correlation & $-0,104$ \\
\hline & Sig. (2-tailed) & ,092 \\
\hline
\end{tabular}

Abbreviations: $\mathrm{VO}_{2 \text { peak, }}$ peak oxygen uptake; $\mathrm{HR}_{\text {peak, }}$ peak heart rate; $\mathrm{HRR}$, heart rate reserve; $\mathrm{W}_{\text {peak, }}$ peak cycling power output 
Table 5 Distribution of individual responses (VT1 and VT2) in patients with the best $(n=55)$ or worst $(n=40)$ physical fitness and their frequency of occurrence in correspondence to the guidelines (in grey)

\begin{tabular}{|c|c|c|c|c|c|c|c|c|c|}
\hline \multirow[b]{2}{*}{ Observations } & \multirow[b]{2}{*}{$\mathrm{VO}_{2 \text { peak }}(\mathrm{ml} / \mathrm{kg} / \mathrm{min})$} & \multicolumn{4}{|c|}{ First ventilatory threshold } & \multicolumn{4}{|c|}{ Second ventilatory threshold } \\
\hline & & $\% \mathrm{VO}_{2 \text { peak }}$ & \%HRpeak & $\% \mathrm{HRR}$ & $\% \mathrm{~W}_{\text {peak }}$ & $\% \mathrm{VO}_{2 \text { peak }}$ & $\% H R_{\text {peak }}$ & $\% \mathrm{HRR}$ & $\% W_{\text {peak }}$ \\
\hline $\mathrm{VO}_{2 \text { peak }}<15 \mathrm{ml} / \mathrm{kg} / \mathrm{min}$ & $12.8 \pm 1.8$ & $68 \pm 9$ & $82 \pm 9$ & $48 \pm 17$ & $53 \pm 11$ & $90 \pm 6$ & $93 \pm 6$ & $78 \pm 17$ & $81 \pm 11$ \\
\hline $\begin{array}{l}\text { Guidelines (\% } \\
\text { prevalence of total } \\
\text { group }\end{array}$ & & $\% \mathrm{VO}_{2 \text { peak }}$ & $\% H R_{\text {peak }}$ & $\% \mathrm{HRR}$ & $\% W_{\text {peak }}$ & $\% \mathrm{VO}_{2 \text { peak }}$ & $\% H R_{\text {peak }}$ & $\% \mathrm{HRR}$ & $\% W_{\text {peak }}$ \\
\hline Low-intense & & 0.0 & 1.8 & 30.9 & 40.0 & 0.0 & 0.0 & 2.0 & 0.0 \\
\hline Moderate-intense & & 18.2 & 7.3 & 49.1 & 54.5 & 0.0 & 2.0 & 9.8 & 15.7 \\
\hline High-intense & & 76.4 & 67.3 & 12.7 & 5.5 & 15.7 & 25.5 & 47.1 & 84.3 \\
\hline Very hard & & 5.5 & 23.6 & 3.6 & 0.0 & 84.3 & 72.5 & 41.2 & 0.0 \\
\hline \multicolumn{10}{|l|}{ Observations } \\
\hline $\mathrm{VO}_{2 \text { peak }} \geq 25 \mathrm{ml} / \mathrm{kg} / \mathrm{min}$ & $28.8 \pm 3.2$ & $54 \pm 10$ & $69 \pm 9$ & $40 \pm 13$ & $44 \pm 11$ & $79 \pm 11$ & $86 \pm 8$ & $73 \pm 14$ & $75 \pm 11$ \\
\hline $\begin{array}{l}\text { Guidelines (\% } \\
\text { prevalence of total } \\
\text { group }\end{array}$ & & $\% \mathrm{VO}_{2 \text { peak }}$ & $\% H R_{\text {peak }}$ & $\% \mathrm{HRR}$ & $\% W_{\text {peak }}$ & $\% \mathrm{VO}_{2 \text { peak }}$ & $\% \mathrm{HR}_{\text {peak }}$ & $\% \mathrm{HRR}$ & $\% \mathrm{~W}_{\text {peak }}$ \\
\hline Low-intense & & 9.5 & 2.4 & 54.8 & 78.6 & 0.0 & 0.0 & 0.0 & 0.0 \\
\hline Moderate-intense & & 64.3 & 64.3 & 35.7 & 16.7 & 7.1 & 2.4 & 19.0 & 21.4 \\
\hline High-intense & & 26.2 & 31.0 & 9.5 & 4.8 & 54.8 & 54.8 & 59.5 & 78.6 \\
\hline Very hard & & 0.0 & 2.8 & 0.0 & 0.0 & 38.1 & 42.9 & 21.4 & 0.0 \\
\hline $\mathrm{p}$-value between groups & $<0.001$ & $<0.001$ & $<0.001$ & 0.004 & $<0.001$ & $<0.001$ & $<0.001$ & 0.067 & 0.011 \\
\hline
\end{tabular}

Abbreviations: $\mathrm{VO}_{2 \text { peak, }}$ peak oxygen uptake; $\mathrm{HR}_{\text {peak }}$, peak heart rate; $\mathrm{HRR}$, heart rate reserve; $\mathrm{W}_{\text {peak, }}$ peak cycling power output 
Figure 1 Study flowchart

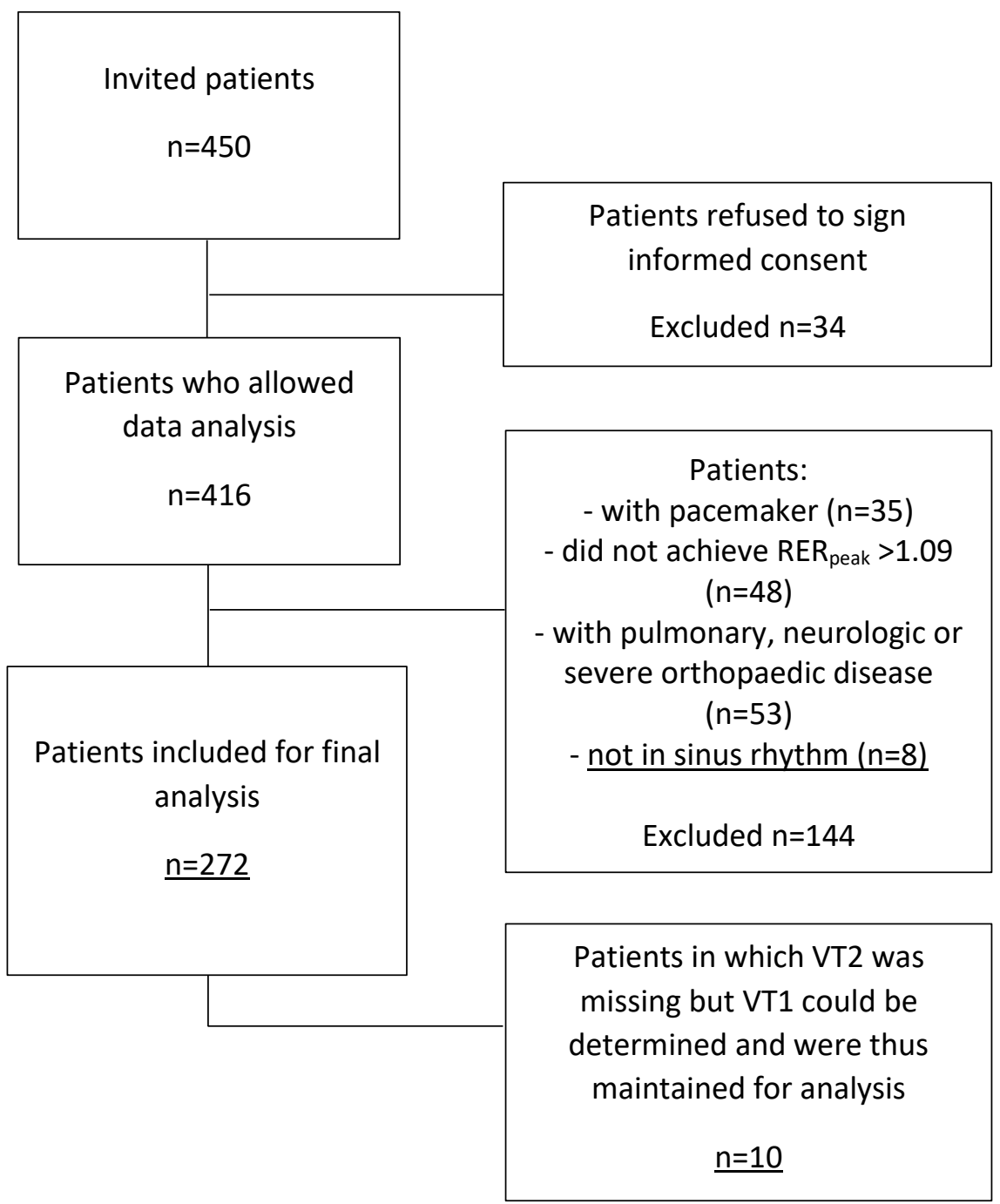

